Rok XVI (2021) | 2 (32) | S. 245-256

https://doi.org/10.12797/LV.16.2021.32.20

Joanna Kubaszzzyk •

Uniwersytet im. Adama Mickiewicza, Poznań

joanna.kubaszczyk@amu.edu.pl

\title{
„ILE PRZEMILCZAM, TEGO NIE WYPOWIEM": \\ O (PRZE)MILCZENIU W UTWORACH WIS ŁAWY SZYMBORSKIEJ \\ I ICH PRZEKŁADZIE NA JĘZYK NIEMIECKI
}

Słowa klucze: przemilczenie, niedopowiedzenie, przekład poezji, przekład emocji, prozodia emocjonalna

Keywords: aposiopesis, understatement, poetry translation, translation of emotions, emotional prosody

\section{Wstęp}

Krystyna Pisarkowa rozpoczyna swą książkę poświęconą pragmatyce przekładu od odwołania się do Księgi Rodzaju, gdzie Jahwe wobec budowniczych wieży Babel wypowiada znamienne słowa: „pomieszajmy tam ich język, aby jeden nie rozumiał drugiego!” (Rdz 11, 7, cyt. za: BT: 32).

Żyjemy w świecie pomieszanych języków. I nie dotyczy to tylko sfery wielojęzyczności, nad którą próbują mniej lub bardziej skutecznie zapanować tłumacze-pośrednicy. Doświadczenie pomieszanego języka, języka, który staje się niezrozumiały dla drugiego, gdy próbujemy wyrazić siebie, jest dużo głębsze, bardziej fundamentalne. Dotyczy przewartościowania słów, przeinaczenia znaczeń.

Wczoraj, kiedy twoje imię ktoś wymówił przy mnie głośno, 
tak mi było, jakby róża

przez otwarte wpadła okno.

Dziś, kiedy jesteśmy razem, odwróciłam twarz ku ścianie.

Róża? Jak wygląda róża?

Czy to kwiat? A może kamień?

- pyta Wisława Szymborska w znanym wierszu Nic dwa razy (Szymborska 2005: 260). Słowa, choć nie wszystkie, mogą mieć śmiercionośną moc, „nie wszystkie słowa // skazują na śmierć", sarkastycznie zauważa poetka w wierszu Z nie odbytej wyprawy w Himalaje (ibid.: 68), a w Niespodzianym spotkaniu gorzko konstatuje „Nasi ludzie nie umieją mówić ze sobą" (ibid.: 92). Język drugiego przestaje być moim językiem. Język drugiego, który mnie rani, narusza moje wartości, skazuje na śmierć cywilną, emocjonalną, relacyjną. Pisarkowa pisze, że „warianty przypadków wymagających pośrednika w komunikacji [...] bywają [...] liczne, wielorakie, nieprzewidywalne" (Pisarkowa 1998: 7). Każda próba zakomunikowania siebie może skończyć się fiaskiem, materia języka - wymknąć się spod kontroli, a zdania i słowa mogą osaczyć swego autora, z czego wyśmienicie zdaje sobie sprawę Szymborska: „Nad białą kartką czają się do skoku // litery, które mogą ułożyć się źle, // zdania osaczające, // przed którymi nie będzie ratunku” (Radość pisania, Szymborska 2005: 10).

By porozumienie mogło zaistnieć, komunikacja nierzadko potrzebuje tłumacza. Kim jest tłumacz? Tłumacz to osoba, „która powinna zrozumieć sensy oryginału bez względu na to, jak trudny czy "przekształcony« kreatywnie jest kod, w którym autor sens swojego dzieła zaszyfrował” (Pisarkowa 1998: 11), a przekład, będąc „zdarzeniem kreatywnym, semiotycznym”, jest jednocześnie „partnerskim aktem komunikacji” (ibid.).

A zatem, odwracając tę logikę, drugi, który mnie rozumie i potrafi odszyfrować moją wypowiedź, jest w jakimś sensie zawsze tłumaczem, uprawiającym przekład intralingwalny w sensie jakobsonowskim, interpersonalny bądź może wręcz „intrarelacyjny” (por. Jakobson 2009: 44). Interpersonalny i intrarelacyjny w sensie, który nakreśla Szymborska w wierszu Złote gody: „Pewnego dnia odpowiedź padła przed pytaniem. // Którejś nocy odgadli wyraz swoich oczu // po rodzaju milczenia, w ciemności” (Szymborska 2005: 88). Sztuka polega tutaj na rozumieniu już nie tylko słowa, ale i milczenia. Odczytanie milczenia staje się największym wyzwaniem. Tłumacz powinien być zatem - znowu oddając głos poetce - niczym archeolog(ia): „Jeżeli tylko zechcę, // (bo czy zechcę, // nie powinieneś być do końca pewien), // zajrzę do gardła twojemu milczeniu" (Archeologia, ibid.: 142).

Czym jest milczenie? K. Pisarkowa odnotowuje w odniesieniu do cytowanego w swej książce tekstu Artura Rubinsteina, iż to „zbudowany z pamięci na faktach i uczuciach tekst literacki” (Pisarkowa 1998: 34). Ale czyż każdy tekst literacki nie jest zbudowany w pewnym sensie z pamięci, na faktach i uczuciach? 
Jakie uczucia skrywa milczenie? Jakie fakty każą zamilknąć? Jakie doświadczenia sprawiają, że o pewnych sprawach lepiej nie rozmawiać? Jak coś powiedzieć, żeby nie powiedzieć? Czy milczenie wypływa z bezsilności? Z kapitulacji po zburzeniu wieży Babel? Ale jest przecież też milczenie zachwytu, oniemienie, milczenie kontemplacji. I w końcu milczenie śmierci, gdy „cisza bez oddechu // to niezła muzyka” (Obmyślam świat, Szymborska 2005: 8). Czy można mówić zatem o polifonii milczenia, bo milczenie niejednym do nas mówi głosem? A gdy milczy kobieta? Czy wymowność milczenia się jeszcze bardziej komplikuje? W końcu kobieta „Musi być do wyboru. // Zmieniać się, żeby tylko nic się nie zmieniło" (Portret kobiecy, ibid.: 90).

„Od wszelkich słów piękniejsze jest Twoje milczenie, bo tyle nim wyrażasz”, odnotowuje polska mistyczka Alicja Lenczewska (2016: 291). Dotychczas rozumiano rolę tłumacza jako pośrednika w świecie wypowiedzianego, w świecie słów. Ale czy tłumacz może i powinien być też pośrednikiem w niewypowiedzianym, przemilczanym? Mistrzem rozumienia ciszy, bezsłowia, słowa zdławionego? Ciszy, która może być złowroga bądź ekstatyczna, pełna resentymentu bądź mistyczna - „Tak wielka jest potęga ciszy i tak słodka cisza Twej miłości - święty Oblubieńcze mój” - pisze dalej Lenczewska (ibid.) w mistycznym uniesieniu.

Cisza wdziera się w tekst poetycki, staje się środkiem wyrazu w sposób szczególny w wierszach Szymborskiej. Może to nie przypadek, że już w dwóch utworach otwierających dwujęzyczne wydanie opusu poetki cisza jest tematyzowana, cisza staje się mową, jak w wierszu Obmyślam świat, gdzie przemawia cisza przyrody, a kto język ten zrozumie, tego ów cud komunikacji „przy życiu umocni”, choć jest to pewna utopia, mrzonka, bo przecież ten obmyślony świat to wydanie drugie, poprawione, nikomu - jak by się wydawało - niepotrzebne, „psom na buty” (Szymborska 2005: 6):

\author{
Mowa Zwierząt i Roślin, \\ gdzie przy każdym gatunku \\ masz słownik odnośny. \\ Nawet proste dzień dobry \\ wymienione z rybą \\ ciebie, rybę i wszystkich \\ przy życiu umocni. \\ Ta, dawno przeczuwana, \\ nagle w jawie słów \\ improwizacja lasu! \\ Ta epika sów! \\ Te aforyzmy jeża \\ układane gdy \\ jesteśmy przekonani, \\ że nic tylko śpi!
}


Ten poprawiony świat to zatem figura raju, w którym każdy rozumie każdego, nawet gdy ten drugi milczy, nawet gdy śpi, a w razie gdyby język drugiego był obcy, „masz słownik odnośny”.

Jednocześnie owo milczenie i cisza to kategoria poetycka, element poetyki Szymborskiej, na co noblistka wskazuje wyraźnie w kolejnym wierszu tomu, Radość pisania, w którym konstatuje: „Cisza - ten wyraz też szeleści po papierze // i rozgarnia // spowodowane słowem »las" gałęzie" (ibid.: 10).

Czy Karl Dedecius, który przełożył wiersze zebrane w tomie, ową ciszę jednak potrafił zinterpretować? Czy potrafił zinterpretować milczenie? Czy zauważył przemilczenie?

\section{Przemilczenie jako kategoria estetyczna}

Przemilczenie jest celowym chwytem oratorskim oraz poetyckim. Internetowy Słownik jezyka polskiego $P W N$ podaje, że polega ono na "na celowym niemówieniu o czymś" (SJP PWN Przem), według zaś Stanisława Sierotwińskiego jest to:

Zaznaczone lub domyślne, jakby puste miejsce, luka w treściowym wypełnieniu konstrukcyjnego schematu utworu. Niekiedy przemilczenie jest wyczuwalne jako spoisty motyw fabularny i wymaga odgadnięcia przez czytelnika jego sensu, bywa też chwytem stylistycznym (Sierotwiński 1986: 198-199).

Autor ten wyróżnia przy tym przemilczenie eliminujące oraz postulujące. Przemilczenie eliminujące to takie, które wynika $\mathrm{z}$ selekcji „przedstawionych elementów rzeczywistości, z wyboru tych, które zostały uznane za ważne, i pomijania nieistotnych" (ibid.: 199), natomiast przemilczenie postulujące wymaga od czytelnika uzupełnienia, rekonstrukcji, domyślności. Jest ono zatem sposobem zaangażowania czytelnika w odbiór tekstu, aktywizacji. Pokrewnym zabiegiem literackim jest niedomówienie, inaczej niedopowiedzenie, polegające na urwaniu zdania bądź innym zaznaczeniu opuszczeń w celu na przykład naśladowania mowy potocznej pod wpływem silnych emocji, stosowane również właśnie jako omówione powyżej przemilczenie postulujące (por. ibid.: 156).

Przemilczenie i niedopowiedzenie zalicza się w retoryce do najważniejszych figur myśli. Retoryka wyróżnia figurę zwaną urwaniem. Mirosław Korolko podaje, iż figura ta, nazwana po grecku aposiópesis, po łacinie zaś reticentia, po polsku oznaczająca „umilknięcie, przerwanie wypowiedzi, niedopowiedzenie”, polega „na przerwaniu wypowiedzi w środku mowy” i pozostawieniu reszty „domysłowi słuchaczy” w celu wywołania różnorakich reakcji, na przykład uczuć takich jak wstyd, gniew, niepokój (Korolko 1990: 115). 


\section{Udosłownienie i dopowiedzenie jako problem przekładu wierszy Wisławy Szymborskiej}

W wierszu Wielka liczba przemilczenie można uznać za jedną z zasad konstrukcyjnych, sama Szymborska tematyzuje je, pisząc: „Ile przemilczam, tego nie wypowiem" (Szymborska 2005: 46). Wobec ogromu świata i jego przejawów podmiot liryczny, który można tutaj, jak sądzę, utożsamić z poetką, zmuszony jest do selekcji i eliminacji: „Wybieram odrzucając, bo nie ma innego sposobu, // ale to, co odrzucam, liczebniejsze jest, // gęstsze jest, natarczywsze jest niż kiedykolwiek" (ibid.). Pierwszy rodzaj przemilczenia to zatem przemilczenie eliminujące, jednak odrzucenie dotyczy nie tylko tego, co nieważne, wręcz przeciwnie - to, co prześlepione, niepomyślane, nieodżałowane, jest gęste i natarczywe. O czym poetka nie mówi? Nie chce mówić? Co przemilcza? Czym są owe nieopisane straty, których kosztem powstaje poezja? Czy to pusty dom obrastający przybudówkami echa? Czy to samotność wśród czterech miliardów ludzi na tej ziemi? Życie zredukowane tylko do pewnych wymiarów („Czy jednak cała żyję, ibid.)? Eliminacja, odrzucenie pewnych życiowych możliwości? Tego, czego podmiot liryczny nie dopowiada, musi domyślić się odbiorca. To on powinien odkryć, jakie są źródła owej przestrzeni wewnętrznej, jakim kosztem ta przestrzeń powstaje.

Owo przemilczenie, niedopowiedzenie jako zasada konstrukcyjna znajduje wyraz również w zastosowanych środkach formalnych. Autorka posługuje się przemilczeniem postulującym. Na poziomie formalnym milknie, przerywa wypowiedzi, nie dopowiada. Już w pierwszej zwrotce czytamy:

Ale tego sam Dante nie zatrzymałby.

A cóż dopiero, kiedy nie jest się.

I choćby nawet wszystkie muzy do mnie (ibid.).

No właśnie, kim się nie jest? Dantem? Tak wielkim poetą jak Dante? Czytelnik zmuszony do dopowiedzenia zaczyna się zastanawiać. Może się też zadumać nad tym, co to właściwie znaczy, że „wszystkie muzy do mnie”.

Czy dochodzi tutaj do głosu typowy dla Szymborskiej sceptycyzm, który poetka dzieli z innymi poetami współczesności? W odczycie noblowskim zaczyna wszak od tego, że „Dzisiejszy poeta jest sceptyczny i podejrzliwy nawet - a może przede wszystkim - wobec samego siebie. Z niechęcią oświadcza publicznie, że jest poetą jakby się tego trochę wstydził” (Szymborska 1996). Czyż zatem owo niedopowiedzenie to wyraz wstydu, że "nie jest się", czy raczej rodzaj rezygnacji, nawet bowiem z pomocą wszystkich muz nie osiągnie się szczytów poezji wyznaczonych przez wielkich poprzedników? W końcu podmiot liryczny nie mówi tubalnym głosem, jego odpowiedź na powołanie to nie głos romantycznego poety-demiurga, lecz ledwie szept poetki-myszki. Przemilczenie staje się wyrazem typowej dla Szymborskiej autoironii. 
Z kolejnym przemilczeniem czytelnik skonfrontowany jest $\mathrm{w}$ drugiej zwrotce, gdy poetka pisze:

Czy jednak cała żyję i czy to wystarcza.

Nie wystarczało nigdy, a tym bardziej teraz (ibid.).

Pierwszy z tych wersów kończy się kropką. W tym miejscu kropka jest rzeczą osobliwą, w normalnym użyciu mowy oczekiwalibyśmy tu znaku zapytania. Użycie kropki jest jednak zabiegiem celowym poetki, zaznacza bowiem koniec zdania, którego część znowu została przemilczana, a które można by uzupełnić choćby tak oto: „Czy jednak cała żyję i czy to wystarcza, żeby nie całkiem umrzeć?”. Kropka wiąże się z intonacją opadającą: to, co podmiot liryczny przemilcza w ten sposób, a co zdradza w piśmie interpunkcja, to zmęczenie, frustracja, może depresja. Ów depresyjny stan, wynikający z rozrachunku z własnym życiem, potwierdza gorzka konstatacja w następnym wersie: „Nie wystarczało nigdy, a tym bardziej teraz”. Na przemilczaną depresję wskazuje też metafora z trzeciej zwrotki tego samego wiersza, gdzie podmiot liryczny, snując refleksję na temat swych snów, stosunkowo bezludnych, mówi o tym, że zbiega z progu w dolinę. Dolina może symbolizować ów stan obniżonego nastroju, cichego smutku, wyobcowania, załamania (por. wyrażenia potoczne mieć dolinę, mieć doła), przeżywanej podświadomie żałoby (obecność w snach zmarłych).

Cóż jednak dzieje się z owym przemilczeniem w przekładzie? Już w przypadku pierwszego przemilczenia, niedopowiedzenia, owego „nie jest się”, które można by uzupełnić „Dantem”, ale też „jak Dante”, Dedecius dopowiada. Jego przekład tego wersu brzmi: „Geschweige denn jemand, der Dante nicht ist” (dosłownie: „Nie mówiąc już o kimś, kto nie jest Dantem”), a i kolejny wers zostaje uzupełniony i brzmi: „Und stünden mir alle Musen auch bei”, czyli: „I nawet gdyby wszystkie muzy mnie wspierały". Przemilczenie postulujące, zmuszające w oryginale czytelnika do wysiłku współtworzenia, znika w przekładzie, ale znika też efekt, który Szymborska w ten sposób osiąga, a mianowicie wrażenie rezygnacji. Gdy bowiem jesteśmy zrezygnowani, bezsilni, często nie dopowiadamy, bo nie mamy siły. W przekładzie niemieckim mamy do czynienia z pewnym stwierdzeniem faktów, ale brak w nim wykładnika emocjonalnego, owej bezsilności myszy u podnóża góry, niemocy wobec nieogarnionej rzeczywistości.

Omówiona powyżej fraza: „Czy jednak cała żyję i czy to wystarcza.” również ulega w przekładzie modyfikacji. Brzmi ona: „Lebe ich aber ganz, und ist das genug?”. W tym miejscu tłumacz konwencjonalizuje, zmieniając kropkę oryginału na znak zapytania, przekształcając tym samym wypowiedź podmiotu lirycznego wyrażającą zrezygnowanie $\mathrm{w}$ zwykłe pytanie retoryczne. $\mathrm{W}$ ten sposób ponownie znikają przemilczane $\mathrm{w}$ oryginale emocje zmęczenia, frustracji, może depresji.

Kolejna modyfikacja dotyczy dodania niewielkiego słówka „da” w przekładzie niezwykle istotnego wersu stanowiącego swoisty rachunek zysków i strat. „Kosztem 
nieopisanych strat - wierszyk, westchnienie" podsumowuje gorzko Szymborska. $\mathrm{Z}$ jednej strony na szali życie w pełni, z drugiej - niepozorna twórczość. Znowu przemilczana frustracja? „Da ein Gedichtchen, dort ein Seufzer („tu wierszyk, tam westchnie") zniemcza Dedecius, co po raz kolejny osłabia wymowę pełnego tragizmu mocowania się ze sobą, czy warto dla sztuki poświęcać życie wśród ludzi, żyć w samotności.

W kontekście poetyki przemilczenia istotną rolę odgrywa również pauza zamykająca przedostatni wers utworu. „Skąd się ta przestrzeń bierze we mnie -”. Padające po pauzie, zamykające wiersz „nie wiem” wybrzmiewa znowu zmęczeniem i rezygnacją. Mimo iż nie mam siły, jest jeszcze we mnie jakaś przestrzeń, można by dopowiedzieć, choć nie wiem skąd. Przeniesienie pauzy na początek ostatniego wersu w przekładzie ponownie zmienia wydźwięk utworu („Wo kommt diese Weite in mir noch her // - ich weiß nicht.”). Kieruje raczej recepcję w kierunku dialogu wewnętrznego, niż jest indykatorem bezsilności, zmęczenia, przygnębienia.

Jednocześnie owo „nie wiem” jest kluczowe dla Szymborskiej, czemu dała wyraz w odczycie noblowskim:

Dlatego tak wysoko sobie cenię dwa małe słowa: „nie wiem”. Małe, ale mocno uskrzydlone. Rozszerzające nam życie na obszary, które mieszczą się w nas samych, i obszary, w których zawieszona jest nasza nikła Ziemia. [...] Poeta [...], jeśli jest prawdziwym poetą, musi ciągle powtarzać sobie „nie wiem”. Każdym utworem próbuje na to odpowiedzieć, ale kiedy tylko postawi kropkę, już ogarnia go wahanie, już zaczyna sobie zdawać sprawę, że jest to odpowiedź tymczasowa i absolutnie niewystarczająca (Szymborska 1996).

Dlatego tak niebezpieczne jest, gdy tłumacz wie, gdy wie za szybko, gdy niefrasobliwie uzupełnia to, co nie zostało powiedziane, co zostało przemilczane. Dlaczego przemilczane? Nie wiem. Ale mogę się jako czytelniczka domyślać, mogę próbować rekonstruować...

Innym wierszem Szymborskiej, w którym pojawia się przemilczenie, jest Portret kobiecy. Już wers inicjujący utwór wskazuje na niedopowiedzenie. „Musi być do wyboru” (Szymborska 2005: 90). I dalej: „Zmieniać się, żeby tylko nic się nie zmieniło” (ibid.). Konstatacja ta brzmi gorzko. Bohaterka Szymborskiej musi się dostosowywać, zmieniać jak kameleon.

Cały wiersz zbudowany jest ze stwierdzeń ubranych odpowiednio w zdania orzekające. Dopiero pod koniec utworu pojawia się pytanie: „Dokąd tak biegnie, czy nie jest zmęczona.”, na które pada odpowiedź: „Ależ nie, tylko trochę, bardzo, nic nie szkodzi." (ibid.). W tej quasi-pytającej wypowiedzi znów znamienne jest użycie kropki, choć oczekiwalibyśmy znaku zapytania. Dedecius zastępując w wersji niemieckiej kropkę pytajnikiem, wygładza tekst i konwencjonalizuje przekaz: „Wo rennt sie so hin, ist sie nicht müde?”. Odpowiedź w przekładzie brzmi: „Doch nein, nur ein wenig, ziemlich, es macht nichts" (ibid.: 91). 
Co zmienia wprowadzenie do tekstu znaku zapytania? Pytajnik wpływa na intonację wypowiedzi. Podczas gdy intonacja zdania pytajnego wznosi się, kropka wskazuje na obniżenie intonacji. Kiedy w wypowiedzi intonacja mimowolnie opada, mimo że powinna się wznosić? Niczym kąciki ust - wtedy, gdy jesteśmy smutni, zmęczeni, zniechęceni, rozczarowani. Jak wiemy, emocje wpływają na ton modalny, w związku z czym mówi się o prozodii emocjonalnej, dzięki której uzewnętrzniają się uczucia nadawcy (Rymarczyk 1999: 136). Niższy ton wiązany jest z przygnębieniem, zmęczeniem, depresją, wyższy - z pozytywnymi stanami emocjonalnymi takimi jak radość czy ekscytacja. Użycie kropki w oryginale, pociągające za sobą intonację opadającą, sugeruje zatem, że w wierszu mamy do czynienia ze swoistym dialogiem wewnętrznym podmiotu lirycznego, który sam przed sobą nie chce się przyznać do zmęczenia, frustracji, może przygnębienia. Są to uczucia, które próbuje wyprzeć. W końcu kobieta dorzuca „nic nie szkodzi”, przyznając, że jest bardzo zmęczona. Pytajnik w przekładzie zmienia tę perspektywę, interlokutorem staje się ktoś zewnętrzny wobec tytułowej bohaterki, a przemilczane uczucia, które odczytać można tylko po tonie głosu, znikają. Mamy zatem tutaj w wierszu dwa rodzaje polifonii - raz słyszymy różne głosy w monologu (czy raczej dialogu wewnętrznym), raz mamy do czynienia z klasycznym dialogiem.

Kolejnym utworem Szymborskiej, w którym pojawia się przemilczenie, jest Pogoń (Szymborska 2005: 64-66). W wierszu interpretacyjnie otwarte jest, kim są „oni”, o których opowiada podmiot liryczny. Czy to anioły bądź inne istoty niebieskie, na co wskazywałaby „boska nieuchwytność”? Czy kosmici („nie po to chodzę po Księżycu”)? Czy wytwory dziecięcej wyobraźni („być dzieckiem, któremu się zdaje”)?

Już pierwsza zwrotka zawiera przemilczenia postulujące:

Wiem, że powita mnie cisza, a jednak.

Nie wrzawa, nie fanfary, nie poklask, a jednak.

Ani dzwony na trwogę, ani sama trwoga (ibid.).

W kolejnych zwrotkach przemilczenie postulujące pojawia się konsekwentnie, w związku z czym można uznać je za zasadę konstrukcyjną wiersza: „mądrości w kulach kryształu, a jednak.” (2 strofa), „Niczego, co by mogło świadczyć, że.” (4 strofa), „Nigdy im włos nie spadnie z głowy, abym miał.” (6 strofa). Ponieważ Szymborska w sposób ewidentny nie dopowiada, nie kończy myśli, K. Dedecius zabieg zauważa i odwzorowuje go w przekładzie, poza szóstą zwrotką, gdzie, niestety, dopowiadając, nadinterpretowuje. Zwrotka ta brzmi w całości tak:

Od wieków znam ich talent do znikania w porę,

ich boską nieuchwytność za rogi, za ogon,

za rąbek szatki rozdętej w odlocie.

Nigdy im włos nie spadnie, abym miał (ibid.). 
Ostatni wers Dedecius tłumaczy: „Kein Härchen fällt ihnen je vom Kopf meinetwegen” (ibid.: 65), co można spolszczyć jako „Nigdy żaden włos nie spada im z głowy ze względu na mnie". Jest to istotne zawężenie, gdyż przemilczenie Szymborskiej można by przecież uzupełnić na przykład tak, że nie spada im włos z głowy, żebym miał jakiś dowód rzeczowy, coś pewnego w ręku oprócz dziecięcej wiary, tlącej się wbrew sceptycyzmowi dorosłego, który odarty ze złudzeń argumentuje: „Nie ma ich, nigdy nie było”. Czy zatem byty, które wydają „Z siebie przeciągłe milczenie”, to tylko fantasmagorie, przydepnięty cień? A może urwane zdania Szymborskiej są zaproszeniem do refleksji metafizycznej? Pozbawiony iluzji dorosły wie wprawdzie swoje, a jednak.

Rozważania te rozpoczęłam od namysłu nad ciszą i milczeniem. Na koniec chciałabym stąd przyjrzeć się jeszcze jednemu utworowi noblistki pod wymownym tytułem Trema i przeanalizować użyte w nim znaki interpunkcyjne, a dokładniej - zwrócić uwagę na kropkę i pauzę (por. Szymborska 2005: 22-24). Trema jest specyficznym zespołem odczuć, wywołującym szereg objawów, między innymi fizjologicznych, gdy głos albo zamiera w gardle, albo się łamie. Człowiek musi zamilknąć, by zapanować nad oddechem, by opanować myśli, gdyż do symptomów tremy należą też objawy poznawczo-emocjonalne. Może to być uczucie niepokoju, strach, wahanie, niepewność. Kropka oznacza zamilknięcie. Kiedy pojawia się zaraz za podmiotem, wypowiedzenie jest niepełne, urwane, zduszone. Tak właśnie, jakby podmiotowi lirycznemu głos utknął w gardle, gdy mówi:

Poeci i pisarze.

Tak się przecież mówi.

Czyli poeci nie pisarze, tylko kto - (ibid.).

Ostatni wers kończy pauza, powtarzająca się regularnie w kolejnych zwrotkach. Pauza oznacza zawieszenie głosu, zamilknięcie. Znów jakby na dłuższy oddech, na zamyślenie, dając może czas na uspokojenie rozkołatanego serca i spanikowanych myśli.

Jakże inny rytm ma przekład - nie ma w nim miejsca na zbędne emocje (por. Lampenfieber, Szymborska 2005: 23-25). Tempo zwiększa się poprzez połączenie wersu pierwszego i drugiego. Pozostało tylko stwierdzenie i pytanie logiczne, pauza bowiem - mimo iż włączona w zdanie - stanowi jedynie chwilowe, retoryczne zawieszenie głosu:

Die Schriftsteller und die Dichter - heißt es allgemein.

Die Dichter sind also - keine Schriftsteller, sondern? (ibid.).

W dalszych zwrotkach przekładu pauza w ogóle znika. Pozostają tylko logiczne konstatacje: 
Poeci to poezja, pisarze to proza -

W prozie może być wszystko, - również i poezja, ale w poezji musi być tylko poezja -

Zgodnie z afiszem, który ją ogłasza przez duże, $\mathrm{z}$ secesyjnym zawijasem $\mathrm{P}$, wpisane w struny uskrzydlonej liry, powinnam raczej wefrunąć niż wejść -

I czy nie lepiej boso, niż w tych butach z Chełmka tupiąc, skrzypiąc w niezdarnym zastępstwie anioła -
Die Dichter sind für die Dichtung. Die Schriftsteller für die Prosa.

Prosa lässt alles zu, auch Dichtung, doch Dichtung nichts als Dichtung, heißt es.

Gemäß dem Aushang, der sie anzeigt mit großem D im Jugendstilgeschnörkel, schön eingezeichnet in die Saiten einer beschwingten Lyra, müßt ich den Saal befliegen eher als betreten

Und besser barfuß als in diesem Schuhwerk aus der Kleinstadt das klopft und knarrt in unbeholfener Vertretung eines Engels (ibid.).

Te pierwsze zwrotki pokazują wyraźnie, że w utworze oryginalnym podmiot liryczny jest pełen wątpliwości. Natomiast w wersji niemieckiej po prostu stwierdza, relacjonuje fakty. Znika wahanie, a przecież - jak już cytowałam wcześniej owo wahanie jest według Szymborskiej kwintesencją postawy poetyckiej, gdyż każda wypowiedź zakończona kropką jest absolutnie niewystarczająca, wymaga rewizji. Co innego, gdy poeta kropki nie postawi - jej brak otwiera przestrzeń, rozszerza horyzonty.

Pominięcie pauzy zmienia nie tylko wydźwięk wiersza. Na skutek wprowadzonych do utworu zmian interpunkcyjnych dochodzi w nim do zaburzenia „powierzchni ikonicznej” w sensie, o którym pisał Antoine Berman (2009: 257).

\section{Podsumowanie}

K. Pisarkowa podkreśla wielką rolę środków pozajęzykowych, współkształtujących wyraz emocji:

[...] naszą komunikację językową wspomagają nieustannie środki pozajęzykowe, w tym muzyczne. Bywają one nie tylko takim brzmieniem, które nazywamy artykułowaniem dźwięków, ale także współkształtowaniem wyrazu emocji, które nawet może sprawiać wrażenie podobieństwa do kodu pojęciowego. Podpatrywanie muzyka, który nadaje „burzy uczuć” kształt muzyczny, może budzić domysł, że ekspresja muzyczna zmierza, podobnie jak ekspresja językowa, od dźwięku nieartykułowanego do porządku zezwalającego na kodyfikację (Pisarkowa 1998: 35).

Jak w muzyce, tak i w poezji, ale przecież i w codziennej komunikacji obok dźwięku czy słowa wielką rolę odgrywa pauza, cisza, milczenie. Ponieważ „[t]ekst poetycki funkcjonuje jako przekaz zaszyfrowany wielowarstwowo i intersemiotycznie” 
(ibid.), tłumacz musi nie tylko pytać o czystą propozycję, ale również zwracać uwagę na treści emocjonalne, zaszyfrowane w tekście, i dążyć „do wydobycia składników istotnych z pozornie drobnych akcentów semantycznych" (ibid.: 36).

$\mathrm{Na}$ koniec warto przypomnieć jeszcze jeden passus z dzieła badaczki, stanowiący doskonałe podsumowanie niniejszych rozważań. Pisarkowa podkreśla w nim, że problem przekładu poezji może leżeć $\mathrm{w}$ niedosłowności użytych $\mathrm{w}$ utworach środków językowych, które nie stanowią kodu pojęciowego, lecz w sposób aluzyjny informują o emocjonalnym sensie całości utworu:

Uogólnienie liryki może się skupiać na sensach i hasłach, które poeta uznał za klucze do tekstu, bo nadał w nich syntetyczną (może być aluzyjną) informację o poznawczym lub emocjonalnym sensie całości. [...] Takich wartości kodu poetyckiego i miejsc, w których się mieszczą, nie wolno przeoczyć. A niebezpieczeństwo kryje się w niedosłowności poezji, w tym, że użyte środki językowe mogą podobnie jak muzyczne nie aspirować do kodu pojęciowego. Są one swoistą próbą przekładu pewnych ogólnych parametrów świata uporządkowanego szczątkami wspólnego języka sprzed zburzenia wieży Babel. Parametry te nie mieszczą się i tak w leksemie, gdyż tworzą jego otoczkę semantyczną w postaci ogólnej konotacji, jak 'radość', 'nadzieja', 'miłość, 'dobro', 'piękno' vs. 'smutek i rozpacz', 'lęk', 'nienawiść, 'zło', 'brzydota' i podobne pierwiastki człowieczeństwa (ibid.: 36).

$\mathrm{Z}$ taką sytuacją nierozpoznania informacji o emocjonalnej wymowie utworu mamy ewidentnie do czynienia w omówionych tekstach. Dlatego na postawione na wstępie pytanie, czy tłumacz powinien być pośrednikiem w niewypowiedzianym, przemilczanym, mistrzem rozumienia ciszy, bezsłowia, słowa zdławionego, trzeba odpowiedzieć zdecydowanie twierdząco. Bez tej wrażliwości trwać będzie nieustannie wzajemne rozmijanie się w komunikacji, co wyśmienicie wyraziła Szymborska w wierszu Na wieży Babel (2005: 194).

Kończąc te rozważania, chciałabym wyrazić wdzięczność i złożyć hołd prof. K. Pisarkowej za liczne inspiracje i intelektualne obdarowania, gdyż, jak sama napisała, „wszystkie nasze własne teksty zawdzięczamy po trosze tym, z którymi rozmawiamy, których słuchamy, których czytamy, do których mówimy i dla których piszemy. Akt komunikacji jest wzajemnym obdarowywaniem się" (Pisarkowa 1998: 36).

\section{Literatura}

Berman A., 2009, Przekład jako doświadczenie obcego, [w:] M. Heydel, P. Bukowski (red.), Współczesne teorie przekładu. Antologia, Kraków, s. 247-264.

BT: Biblia Tysiąclecia. Pismo Święte Starego i Nowego Testamentu w przekładzie z języków oryginalnych, oprac. zespół biblistów polskich z inicjatywy Benedyktynów Tynieckich, wyd. 3 popr., Poznań - Warszawa 1980.

JАКовSON R., 2009, O językoznawczych aspektach przekładu, [w:] M. Heydel, P. Bukowski (red.), Współczesne teorie przekładu. Antologia, Kraków, s. 43-49. 
Korolko M., 1990, Sztuka retoryki. Przewodnik encyklopedyczny, Warszawa.

Lenczewska A., 2016, Świadectwo. Dziennik duchowy, Poznań.

Pisarkowa K., 1998, Pragmatyka przekładu. Przypadki poetyckie, „Prace Instytutu Języka Polskiego", nr 106, Kraków.

RyMARCZY K K., 1999, Zaburzenia prozodii emocjonalnej i lingwistycznej u pacjentów z uszkodzeniami mózgu, „Przegląd Psychologiczny” t. 42, nr 1-2, s. 135-150.

Sierotwiński S., 1986, Słownik terminów literackich. Teoria i nauki pomocnicze literatury, wyd. 4, Wrocław.

SJP PWN Przem: Słownik języka polskiego PWN, hasło: Przemilczenie, [on-line:] https://sjp. pwn.pl/sjp/przemilczenie;2510662.html (dostęp: 8 IV 2021).

Szymborska W., 1996, Poeta i świat: odczyt noblowski, [on-line:] https://www.nobelprize. org/prizes/literature/1996/szymborska/25586-wislawa-szymborska-odczyt-noblowski-1996/ (dostęp: 31 III 2021).

Szymborska W., 2005, Hundert Gedichte - Hundert Freuden. Sto wierszy - sto pociech, wybór, przekł. i posłowie K. Dedecius, wyd. 4, Kraków.

\section{"How Much I Dissemble I shall not Utter": on Aposiopesis in the Poems by Wisława Szymborska and Their Translation into German Abstract}

Krystyna Pisarkowa emphasises the importance of means which participate in shaping the expression of emotions in a poetic text, and calls for extracting from the text "essential ingredients from seemingly minor semantic accents" (Pisarkowa 1998: 36). In this article, the author takes this inspiration and analyses how Wisława Szymborska applies silence in her poems as an aesthetic category and an expression of choked emotions, what indicators of silence she uses, and what happens with this silence in the translation of her poems into German by Karl Dedecius. The author concludes that a translator should be able to empathise with emotions and be an intermediary not only for the word, but also for the unspoken. 